\title{
Freshwater Use in Delaware, 2000
}

\author{
by Judith $\mathrm{C}$. Wheeler
}

This Fact Sheet describes the results

of a water-use study for the State of Delaware that was conducted by the U.S. Geological Survey (USGS), in cooperation with the Delaware Geological Survey (DGS) and the Delaware Department of Natural Resources and Environmental Control (DNREC), as part of the National Water-Use Information Program of the USGS. The Program is based on Federal and State cooperative agreements to collect, store, and disseminate water-use information nationally and locally.

As the demand for freshwater increases, the stress placed on the surface-water and ground-water resources of Delaware increases. Effective water-resource management depends, in part, on up-to-date and accurate water-use data. Such data are valuable for evaluating the effects of withdrawals on the State's water resources, identifying current water-use patterns, and estimating future water demands.

Together, DNREC and USGS collect, compile, estimate, and store site-specific and aggregated water-use data that are useful for water-resources management in Delaware.

Delaware water-use data have been published in reports such as the Water 2020 series (Water Resources Agency for New Castle County, 1990) and USGS publications by Wheeler (1999) and Phelan (1987, 1990). Delaware water-use data also are included in USGS National WaterUse Circulars, published every 5 years since 1950. State data for 1995 are in USGS Circular 1200, "Estimated Use of Water in the United States in 1995" (Solley, Pierce, and Perlman, 1998).
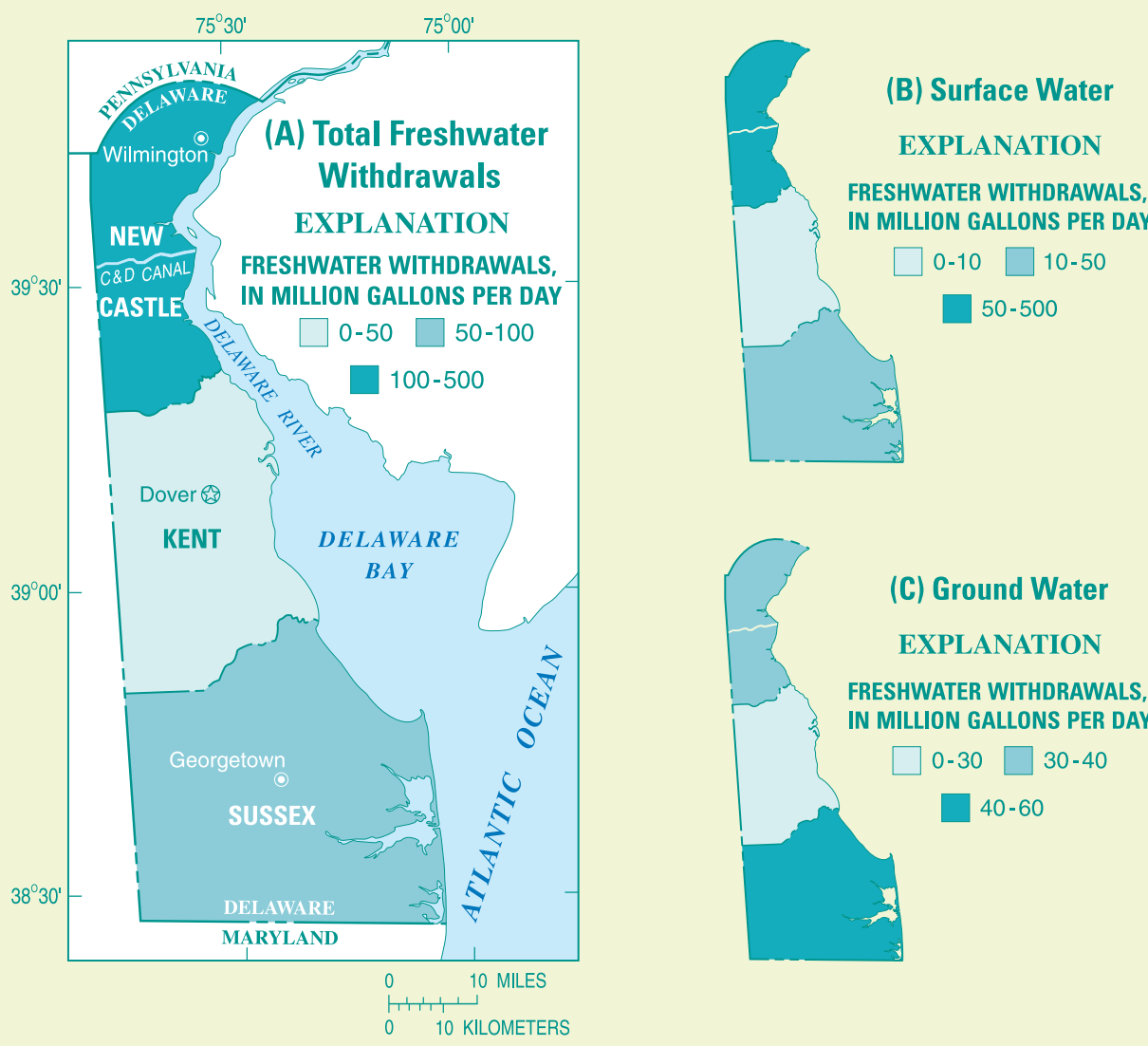

FRESHWATER WITHDRAWALS, IN MILLION GALLONS PER DAY 0-30 $\square$ 30-40 40-60

Figure 1. Freshwater withdrawals in Delaware by County, 2000. (A) Total freshwater withdrawals; (B) Fresh surface-water withdrawals; and (C) Fresh ground-water withdrawals.

\section{Total Freshwater Withdrawals}

Water users may be self-supplied (withdrawing water from a surface-water or ground-water source) or receive water from a public-supply system or both. Water withdrawn by a public or private water purveyor and delivered to a variety of users is designated as a "public supply." Homes and small communities relying on individual wells are classified as domestic "selfsupplied" water users.

Thermoelectric power includes water used for the generation of electricity by steam-electric plants fueled by conventional fuels. Commercial use includes not only businesses such as restaurants, motels, and car washes, but also institutions such as churches, schools, and military installations. Most of the withdrawal data presented in this report were obtained from DNREC; however, some water-use data, such as withdrawals for domestic, irrigation, and livestock watering, were estimated using water-use coefficients.

During 2000, about 584 Mgal/d (million gallons per day) of freshwater was withdrawn from surface-water and groundwater sources in Delaware. Surface-water sources provided 80 percent $(467 \mathrm{Mgal} / \mathrm{d}$ ) of all freshwater used in Delaware during 2000. About 80 percent (366 Mgal/d) of surface-water withdrawals were for cooling condensers in thermoelectric power generation; nearly all of the water withdrawn was returned to the surface-water source. Ground-water sources provided 20 percent (117 Mgal/d) of all freshwater used in Delaware during 2000. Most ground-water withdrawals (57 percent, or about 67 $\mathrm{Mgal} / \mathrm{d}$ ) were from the surficial unconfined aquifer, followed by the Potomac Group aquifers, which supplied about $22 \mathrm{Mgal} / \mathrm{d}$, the Cheswold Group aquifers with about $15 \mathrm{Mgal} / \mathrm{d}$, and the Piney Point and Aquia aquifers with about $7 \mathrm{Mgal} / \mathrm{d}$. The remaining $6 \mathrm{Mgal} / \mathrm{d}$ of ground-water withdrawals were supplied by the Mount Laurel, Piedmont, and carbonate aquifers. Withdrawals of freshwater by county and water source are shown in figure 1 .

The demand for freshwater in

Delaware is highest in the densely populated and industrialized northern part of the State, and lowest in the agricultural central and southern parts. Generally, water supplies are adequate in all areas of the State. Sometimes, however, available water supplies are marginal or less than adequate in meeting demands, such as during low-flow periods and high seasonal-demand periods, particularly in New Castle County (north- 
ern Delaware) (fig.1), (Stewart Lovell, Delaware Department of Natural Resources and Environmental Control, oral commun., 1998).

New Castle County has the largest population in the State (about 500,000 people) and freshwater withdrawals in the County account for 79 percent (462 $\mathrm{Mgal} / \mathrm{d}$ in 2000) of all freshwater used in the State. Most of the water withdrawn (nearly 93 percent) is surface water and is used for cooling in the production of electricity (366 Mgal/d) and for public-supply distribution (50 Mgal/d). Kent County, in the central part of the State, has a population of about 127,000 and freshwater withdrawals account for about 5 percent (31 $\mathrm{Mgal} / \mathrm{d}$ in 2000) of the total freshwater used in the State; almost 90 percent of the water used in this County is ground water. Nearly 75 percent of the water used in the County is withdrawn for agricultural irrigation (12 Mgal/d) and public-supply distribution (10 Mgal/d). Sussex County, in the southern part of the State, has a population of about 157,000. Freshwater withdrawals in the County account for about 16 percent (91 Mgal/d in 2000) of the freshwater used in the State; about 60 percent of this water (55 Mgal/d) is from ground-water sources and is used primarily for publicsupply distribution (13 Mgal/d) and irrigation (24 Mgal/d). Most of the fresh surface water withdrawn in the County $(32$ $\mathrm{Mgal} / \mathrm{d}$ ) is used by industries.

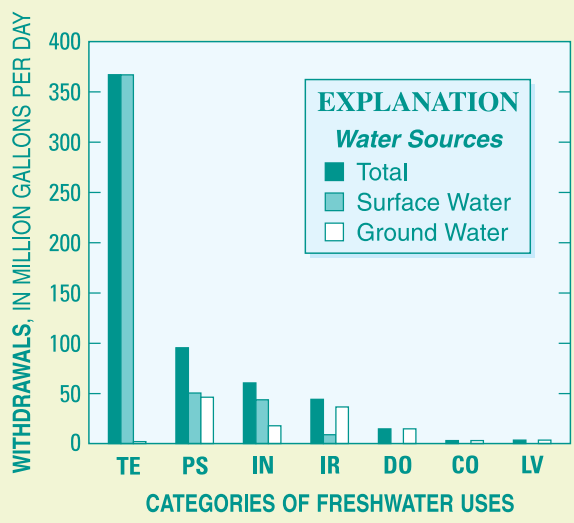

[TE, Thermoelectric Power; PS, Public Supply; IN, Industrial; IR, Irrigation; DO, Domestic; CO, Commercial; LV, Livestock]

Figure 2. Freshwater withdrawals in Delaware, by category of use and water sources, 2000.

\section{Types of Freshwater Use}

During 2000, the major uses of freshwater in Delaware included thermoelectric power, public supply, industrial, irrigation, domestic, commercial, and livestock watering (fig. 2).

\section{Thermoelectric Power}

Freshwater withdrawals by thermoelec- tric powerplants during 2000 were 366 $\mathrm{Mgal} / \mathrm{d}$, nearly all of which was from surface-water sources. Most of the surface water was used for cooling condensers and then returned to the water source. Only about $0.47 \mathrm{Mgal} / \mathrm{d}$ was from ground-water sources and about $0.65 \mathrm{Mgal} / \mathrm{d}$ was delivered from public suppliers.

\section{Public Supply}

More than 300 public water-supply systems in Delaware provide water to about 617,000 people (79 percent of the State's population). Total withdrawals for public supply during 2000 were 95 $\mathrm{Mgal} / \mathrm{d}$, of which $50 \mathrm{Mgal} / \mathrm{d}$ was from surface-water sources and $45 \mathrm{Mgal} / \mathrm{d}$ was from ground-water sources.

The largest withdrawals for public supply were in New Castle County (72 $\mathrm{Mgal} / \mathrm{d}$ ). Of this amount, $50 \mathrm{Mgal} / \mathrm{d}$ was from surface-water sources and $22 \mathrm{Mgal} / \mathrm{d}$ was from ground-water sources. Public suppliers in Kent and Sussex Counties relied solely on ground-water sources and withdrew $10 \mathrm{Mgal} / \mathrm{d}$ and $13 \mathrm{Mgal} / \mathrm{d}$, respectively.

\section{Industrial}

During 2000, about $73 \mathrm{Mgal} / \mathrm{d}$ of freshwater was used by industries in Delaware, primarily for making chemicals, plastics, and food products. Of this amount, $14 \mathrm{Mgal} / \mathrm{d}$ was provided by public suppliers. The remaining $59 \mathrm{Mgal} / \mathrm{d}$ was self-supplied, of which $42 \mathrm{Mgal} / \mathrm{d}$ was from surface-water sources and $17 \mathrm{Mgal} / \mathrm{d}$ was from ground-water sources. Sussex County had the most withdrawals for industrial use (39 Mgal/d), followed by New Castle County with $18 \mathrm{Mgal} / \mathrm{d}$, and Kent County with $2 \mathrm{Mgal} / \mathrm{d}$.

\section{Irrigation}

The amount of freshwater used for irrigation can vary from year to year and among users. Differences in rainfall distribution, crops grown, and soil type are important factors in determining how much and when water is applied. During 2000, about $43 \mathrm{Mgal} / \mathrm{d}$ of freshwater was used for irrigation of primarily farm crops, golf courses, and nursery stock. Of this amount, $8 \mathrm{Mgal} / \mathrm{d}$ was from surface-water sources and $35 \mathrm{Mgal} / \mathrm{d}$ was from groundwater sources.

\section{Domestic}

Domestic users in Delaware obtain freshwater from public suppliers and from their own wells (self-supplied). During 2000, total use (withdrawals and deliveries) was $63 \mathrm{Mgal} / \mathrm{d}$, of which $50 \mathrm{Mgal} / \mathrm{d}$ was delivered by public suppliers. About 166,000 residents (21 percent of the State's total population) withdrew about 13 $\mathrm{Mgal} / \mathrm{d}$ from individual house wells for water supply.

\section{Commercial}

Commercial users obtained freshwater from public suppliers and from self-supplied sources. Total commercial use during 2000 was $23 \mathrm{Mgal} / \mathrm{d}$, of which about 21 $\mathrm{Mgal} / \mathrm{d}$ was provided by public suppliers. The remaining $2 \mathrm{Mgal} / \mathrm{d}$ was self-supplied and came from ground-water sources.

\section{Livestock}

During 2000, about $3.99 \mathrm{Mgal} / \mathrm{d}$ of freshwater was used for livestock activities, mainly livestock watering, feedlot, dairy operations, and aquaculture. Of the total water withdrawn, $0.22 \mathrm{Mgal} / \mathrm{d}$ was from surface-water sources and $3.77 \mathrm{Mgal} / \mathrm{d}$ was from ground-water sources. Sussex County withdrew the most water for livestock use (3.04 Mgal/d), followed by Kent County with $0.86 \mathrm{Mgal} / \mathrm{d}$, and New Castle County with $0.09 \mathrm{Mgal} / \mathrm{d}$.

\section{Selected References}

Hodges, A.L., Varrin, R.D., and Cherry, P.J., 1990, Delaware water supply and use in U.S. Geological Survey, 1990, National water summary 1987-Hydrologic events and water supply and use: U.S. Geological Survey Water-Supply Paper 2350, p. 201206.

Phelan, D.J., 1987, Water levels, chloride concentrations, and pumpage in the Coastal Plain aquifers of Delaware and Maryland: U.S. Geological Survey Water-Resources Investigations Report 87-4229, 106 p.

, 1990, Water use in the St. Jones River Basin, Kent County, Delaware, 1983-86: U.S. Geological Survey Water-Resources Investigations Report 90-4094, 30 p.

Solley, W.B., Pierce, R.R., and Perlman, H.A, 1998, Estimated use of water in the United States in 1995: U.S. Geological Survey Circular 1200, $71 \mathrm{p}$

Water Resources Agency for New Castle County, 1990, Water 2020 series, Volume III, Water use in New Castle County: Newark, Delaware, Water Resources Agency for New Castle County, 33 p.

Wheeler, J.C., 1999, Freshwater use in Delaware, 1995: U.S. Geological Survey Fact Sheet FS-126-99, 2 p.

For additional information contact:

District Chief

U.S. Geological Survey

8987 Yellow Brick Road

Baltimore, Maryland 21237

or visit the Maryland-Delaware-D.C. District Homepage on the World Wide

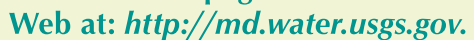

The USGS National Water-Use Program website is: $\boldsymbol{h t t p}: / /$ water.usgs.gov/watuse.

FS 111-03

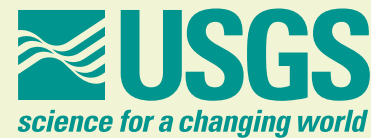

